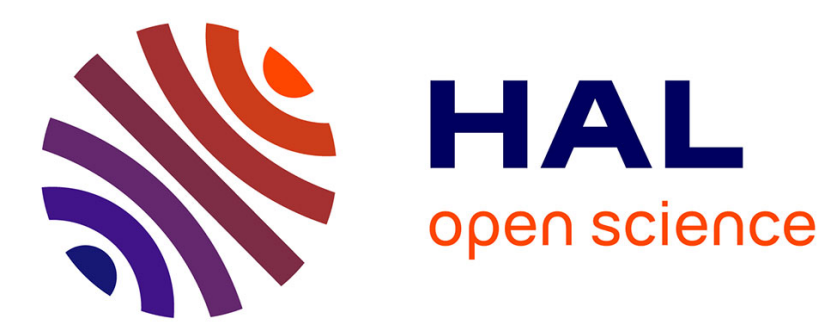

\title{
Preliminary Study Impact of Building Information Modelling Use in Malaysia
}

\author{
W. I. Enegbuma, A. C. Ologbo, U. G. Aliagha, K. N. Ali
}

\section{To cite this version:}

W. I. Enegbuma, A. C. Ologbo, U. G. Aliagha, K. N. Ali. Preliminary Study Impact of Building Information Modelling Use in Malaysia. 11th IFIP International Conference on Product Lifecycle Management (PLM), Jul 2014, Yokohama, Japan. pp.51-62, 10.1007/978-3-662-45937-9_6 . hal01386475

\section{HAL Id: hal-01386475 \\ https://hal.inria.fr/hal-01386475}

Submitted on 24 Oct 2016

HAL is a multi-disciplinary open access archive for the deposit and dissemination of scientific research documents, whether they are published or not. The documents may come from teaching and research institutions in France or abroad, or from public or private research centers.
L'archive ouverte pluridisciplinaire HAL, est destinée au dépôt et à la diffusion de documents scientifiques de niveau recherche, publiés ou non, émanant des établissements d'enseignement et de recherche français ou étrangers, des laboratoires publics ou privés. 


\title{
Preliminary Study Impact of Building Information Modelling Use in Malaysia
}

\author{
Enegbuma, W. I. ${ }^{1}$, Ologbo, A. C. ${ }^{2}$, Aliagha, U. G. ${ }^{3}$ and Ali, K. N. ${ }^{4}$ \\ ${ }^{1,4}$ Faculty of Built Environment, ${ }^{2}$ Faculty of Management \\ ${ }^{3}$ Faculty of Geoinformation Science \\ Universiti Teknologi Malaysia, 81310 Skudai, Johor. \\ 1wenegbuma2@live.utm.my
}

\begin{abstract}
The paradigm shift in the construction industry from 2D to Building Information Modelling (BIM) presents unforeseen challenges for new entrant construction industries. Experiences from advanced industry users of BIM shape the directions for future use. In Malaysia, BIM maturity is fast appreciating with increasing demand for efficiency and competitive advantages. However, adoption rate encounters resistance from several factors highlighted in previous research: people, process and technology. To improve on Information technology (IT) adoption models factors such as business process re-engineering, computer integrated construction and BIM adoption were considered for this research. This paper represents findings of an ongoing research, presenting the designed questionnaire to access perception of construction industry professionals (Architects, Quantity Surveyors, Engineers and Contractors) knowledge on BIM softwares and BIM attributes. Responses were derived from 120 construction professionals in the pilot phase of the research. The data is analyzed using SPSS for a descriptive overview of the most prominent BIM software usage. Smart PLS was utilized to analyze the path coefficient effects of each variable in the model. The Cronbach Alpha derived fell within an agreeable minimum threshold of above 0.60 . The factors loaded appropriately to each variable. The path coefficient revealed people perception had the highest effect on collaborative processes, business process re-engineering (BPR) had the highest effect on BIM adoption and model variance R2 explained $24.6 \%$ of BIM adoption. The results will demonstrate the current state of BIM adoption in Malaysian construction industry complimenting current efforts to improve BIM awareness. At this stage, future research focuses on developing the second phase of the model and recommends towards extending and redefining the model with other mediating variables.
\end{abstract}

Keywords: Building Information Modelling (BIM), Construction Industry, Information Technology, Malaysia, Partial Least Square (PLS).

\section{Introduction}

Building Information Modeling is predominantly viewed as collaboration by different stakeholders at different phases of the life-cycle of a facility to insert, extract, update or modify information in the model to support and reflect the roles of that stakeholder. The model is a shared digital representation founded on open 
standards for interoperability. BIM as the process of generating and managing building data during its life cycle. National Building Information Modeling Standard (NBIMS) views BIM as a digital representation of physical and functional characteristics of a facility [1]. The Malaysian Construction Industry Development Board (CIDB) ten-year construction industry master plan (CIMP) to refocuses on the strategic position and future direction of the industry breeding an innovative, sustainable, professional, profitable and world-class construction industry. Important to this study is the leverage on IT towards achieving the set vision of 2015. The dimensions to building information modelling (BIM) research is inexhaustible in fields of user perception, health and safety, costing, project management, green building, Off-Site Manufacturing (OSM), Integrated Project Delivery (IPD), self help housing and real estate [5] [6] [7] [8]. Information technology IT transforms and plays a vital role in how innovation affects project delivery in Malaysian construction sector. The Malaysian governments' aggressive drive to developed nation and exportation of construction services to India and South-East Asia intertwined with government-to-government projects favoured BIM propagation. Design technology is key to affordance of a project hence, choice and collaboration should commerce at the earliest stage. BIM implementation brings unsettling effect to technology, people and processes/policy, process and technology [9]. BIM implementation produces various impacts on both internal organisational culture and values; and external supply chain. Changes in delivery processes, shift from individual consulting to consultancy team, contractor involvement on projects, improved shared vision and trust amongst teams, rise in supply chain effectiveness, automatic building permission [10] [7] [8] [1]. Amidst such process improvement potentials through BIM also exists challenges to full system automation (knowledge; resistance; political engagement; technology capabilities; skills gaps; costs; new forms of contracts; legal issues; life cycle benefits; relevant training and data standards [11] [10] [7] [12]. This study presents pilot results for the Enegbuma and Ali [6] model aimed at plotting a path towards linking user perceptions of people, process and technology and focuses on how they react in strategic IT implementation for effective BIM penetration in the industry. Subsequent sections will delineate the variables of the BIM model, present the hypotheses, examine the data findings and discusses by re-visiting the earlier stated hypothesis.

\section{$2 \quad$ BIM Penetration Model}

People perception from previous research in BIM has highlighted the seemingly increasing effect of people dimension to BIM use [14] [2] [15-19]. This paper therefore defined people as the perception towards adapting to new BIM practices in the industry. BIM emergence offers an unsettling precedence to an already defragmented construction industry which offers less surety. New processes to enhance the construction process, electronic designs and construction professionals must acknowledge the individual risk associated with such a new technology. Boundaries of professional responsibility and work product are not clearly defined creating uncertainty for liability in a BIM model. The trend of older professionals still lagging behind while younger professionals lack experience in legal matters with a need for flexible legal form of agreement between construction teams to meet the rapid growth [14] [2] [15]. The emergence of local user Groups in various localities to discuss BIM concepts, softwares and products including information sharing on 
achievements has shown an adaptive response by people for BIM improvements [16]. Owner awareness is lacking in terms of information regarding successes of BIM by other competitive companies in operation, maintenance, repair and re-modelling. While, other seminar authors proposed a future expansion of current pedagogy in education of building professionals [17-18]. Hence the role of people perception is taken into consideration as it affects BIM penetration in the construction industry.

Process perception changes are inherent in affecting BIM use [13] [6] [1] [20] [2123] [14] [19]. This paper defines such process thereof as how perception related to managing process changes in adapting to new BIM practices in the industry. Previous construction industry reports except the Latham 1994 report have ignored IT as an integral process in construction. However, emphasis on technology development alone places less attention to organisational and human issues. Furthermore, fewer staffs to regularly update BIM models and inadequate human resource training exist in the construction industry [20] [4] [21-22]. For smooth BIM implementation within an organisation strict consideration must be given to the long term goals of the organisation and requirement. Similarly, managing the cost of ownership can be actualised through BIM, with diligent improvement in BIM practices owners' BIM metamorphoses into a Business Intelligence Model placing it right within corporate mission and objectives. Similar to the CAD migration, BIM is faced with challenging bureaucracy by top management due to new risk and liability fears during model sharing [23] [14]. BIM implementation in the US coast guard achieved partial success. Full success was eventually marred by people's culture and senior leadership resistance to new methodologies; workflow changes; and technological innovation [3].

Technological Perception role presents significant impact on BIM use [25] [5] [26]. Owner push for faster product delivery improvement, safer construction environment, reduced construction cost, lean adoption to eliminate waste and proactive drive by industry professionals to assimilate new technology such as BIM [14]. Malaysian construction industry grapples in advanced IT and project management techniques which forms an essential part to high-tech and capital intensive construction [24]. McGraw-Hill construction report suggests that for BIM to strive and meet the challenges of the future, model objects needs to be readily available for smooth information extraction. Although, product library were created by software companies to represent generic components they lack enough data to represent the specifications of Building Product Manufacturers (BPMs). Knowledge of BIM software, inadequate reference material and component database provide challenges in BIM education in tertiary institutions. Inherent deficiencies in BIM specification provide inadequate differentiation between requirement for BIM deliverables and technology to deliver such information. Similarly, during hyper collaborative platforms such as BIM Storm, participants had to revert to do some manual communication [25] [5] [26].

Strategic IT Planning in line with industry transformation, from adversarial to cooperative thinking places more emphasis on business process. Construction industry is transforming into long term strategic planning to cope with the dynamic nature of economic, technological and social factors. Strategic IT usage though perceived with a degree of reluctance by the construction industry is currently transforming, as most business process were never designed but formed by ad hoc means. Research in labour and cost saving by Adam Smith and Fredrick Taylor provided an initiating argument towards a re-think of business process [27]. 
Sustainable competitive advantage is maintained though innovative process improvement and management reliant on IT to provide enabling environment [28]. ICT showed a positive and significant impact on the Malaysian economy from 1982 2004 which established a change from the norm of investments on agrarian economy to one of manufacturing and industrialisation [29]. Technology acceptance and usage has been studied extensively, expanding Fishbein and Ajzen Model of 1975, Fred Davies formulated the technology acceptance model (TAM). Fishbein and Ajzen Model explained the theory of reasoned action, which Davies conceptualised the existence of a response predicted by user motivation and influenced by external stimulus consisting of the system features and capabilities which triggered the use of a system. [30] perceived change to be structured and measured sets of activities designed for a specific product for various markets and clientele. In construction, process change from inception, project completion and FM stages provide benefits to clients in Malaysian construction industry. Business Process Re-engineering (BPR) drives organization to change their career paths, training, recruitment and policies [31]. Factors highlighted in driving BPR are organisational training, reward, communication, research and development [32]. This paper considers business process re-engineering and computer integrated construction aspects of strategic IT planning.

Collaboration in construction is defined as an agreement among specialist to share their abilities in a particular process, to achieve the larger adjectives of the project as a whole, as defined by a client, a community, or a society at large. Collaboration is working together in a seamless team for common objectives that deliver benefit to all. Collaboration is more effective when undertaken at the project inception stage [33]. Construction industry presents a rather unique approach to collaborating which when done ineffectively creates islands of automation [34]. Major challenges to effective collaboration exist in the construction industry due to independent working and taking decisions which affects the project team [35]. Issues bordering around undefined boundary between teamwork and collaboration including, unsolved issues of sharedunderstanding, alignment of purpose and shared meaning. Different educational upbringing, terminologies and adversarial contractual agreement further provides barriers to collaboration [36]. This paper adopts collaborative construction as a means improving BIM penetration in the industry.

BIM Penetration amongst other benefit derives competitive gains and future guiding policies of new systems. Communication of innovation over time amongst members of the same social systems over a period of time is often referred to as a product of complex social interaction. Social system acts as a determinant of sociopsychological processes within the social system [37]. Diffusion describes the acceptance and usage of new technology while innovation denotes a new product or process technology, or administrative. Innovation diffusion proposes new models of diffusion of new technologies with complimentary implications for increasing the rate of innovation in the industry. Furthermore, investigations identified four forces that drive innovation: competitive advantage, process problems, technological opportunity, and institutional requirements [38]. [39] argued that relative advantage, compatibility, complexity, observability and triability are determining factors for technology diffusion. The structural equation modelling path study towards improving innovation diffusion level within the architectural and engineering design (AED), delineated 
definitive pathways and practical strategies harnessed by the construction industry to derive outcomes from innovation via diagnosing and improving their existing innovation capability which invariably strengthen their business performance [37].

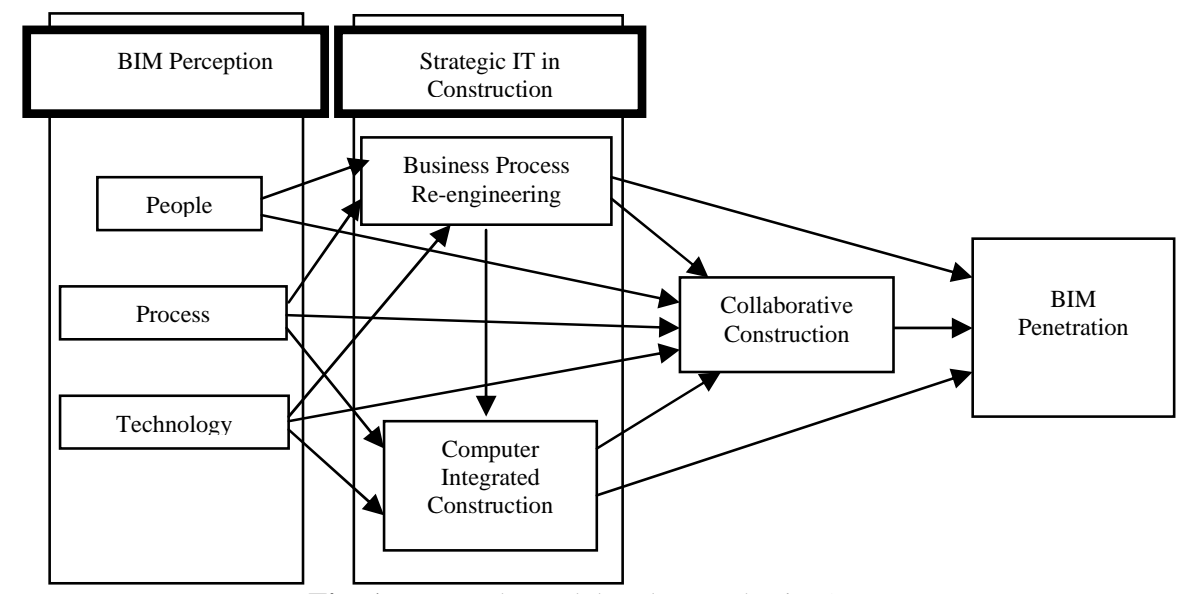

Fig. 1. Research Model and Hypothesis [1]

Table 1. Generated Hypothesis

\begin{tabular}{lr} 
H1 & There is a positive relationship between People and Business Process Re-engineering \\
H2 & There is a positive relationship between Process and Business Process Re-engineering \\
H3 & There is a positive relationship between Technology and Business Process Re-engineering \\
H4 & There is a positive relationship between Process and Computer Integrated Construction \\
H5 & There is a positive relationship between Technology and Computer Integrated Construction \\
H6 & There is a positive relationship between People and Collaborative Construction \\
H7 & There is a positive relationship between Process and Collaborative Construction \\
H8 & There is a positive relationship between Technology and Collaborative Construction \\
H9 & There is a positive relationship between Business Process Re-engineering and BIM Penetration \\
H10 & There is a positive relationship between Business Process Re-engineering and Collaborative Construction \\
H11 & There is a positive relationship between Business Process Re-engineering and Computer Integrated \\
H12 & There is a positive relationship between Computer Integrated Construction and Collaborative Construction \\
H13 & There is a positive relationship between Computer Integrated Construction and BIM Penetration \\
H14 & There is a positive relationship between Collaborative Construction and BIM Penetration \\
\hline
\end{tabular}

\section{$3 \quad$ Methodological Approach}

In structural equation modelling, dual techniques separate the chosen method of analysis namely; covariance-based methods [40] or variance-based PLS-SEM approach [41]. Prevalent in strategic management research is the use of PLS-SEM approach, since this BIM pilot study targets a strategic approach to improving BIM penetration in the construction industry, PLS-SEM was chosen. BIM penetration construct represents a more variance-based (prediction oriented) approach [43]. Other aspects to fortify the methodology technique include increased level of statistical power in small sample size [44] and less rigid assumption [45]. Smart PLS 2.0 [46] was used in evaluating the path model and parameter estimation to evaluate the path weighting scheme [43]. The guidelines by [47] were followed in reporting the measurement model values and subsequent structural model. The constructs were 
measured by means of multiple items using a five-point Likert scale ranging from 1 (disagreement) to 5 (agreement) [48]. Due to inadequate specific research in contrition IT regarding BIM penetration, items to measure the constructs were reworded and some generated by the authors from previous literature. Hence the need arose to revalidate the reliability of items. Strict attention was placed on confining the multi-item measures to denote representatively the underlying construct.

\section{$4 \quad$ Results and Discussion}

The demographic nature of the respondents showed that Engineers made up 36.7\% of the respondents. Male respondents were more with $73.3 \%$. The age bracket of 2535years was predominant by $66.7 \%$. $36.7 \%$ of the respondents are originally from Federal Territory of Kuala Lumpur. 83.3\% carry out their construction activities from the private sector. $53.3 \%$ represents the junior management community in the various establishments. $66.7 \%$ are qualified with a bachelor in the outlined fields of construction. $50.0 \%$ majority have been active in construction for 6 -10years. $50.0 \%$ are registered in their various professional affiliations. $50.0 \%$ are of the opinion that their level of BIM involvement falls within the beginner class.

The initial pool of item amounted to 48 namely; People (RPPB) - 12, Process (RPP) - 7, Technology (RTP) - 6, Business Process Re-Engineering (RBPR) - 6, Computer Integrated Construction (RCIC) - 6, Collaborative construction (RCC) - 5 and BIM penetration (RSBP) - 6. The first stage of Alpha analysis via SPSS revealed a low Cronbach Alpha for constructs RPPB (0.606), RBPR (0.496), RCIC (0.546) and RCC (0.490). Subsequently, from the Item-Total Statistics item suggested to be deleted to raise the minimum alpha threshold were delete RPPB9, RBPR4, RCIC3 and RCC5 respectively. The final Cronbach Alpha for the constructs are above the minimum threshold of $>0.60$ [49].

The path diagram linking all constructs was drawn in Smart PLS and analysis initiated by PLS algorithm. The default PLS algorithm settings were utilised; weighting Scheme (Path Weighting Scheme), Data Metric (Mean 0, Variance 1), Maximum Iterations (300), Abort Criterion (1.0E-5) and Initial Weights (1.0). In Smart PLS the factor loadings are derived from the outer loading result which showed low values $<0.50$. Lowest value loadings were deleted. Discriminant validity holds with all factors loadings in respective variables derived from the PLS cross loading. Convergence occurred at 9 iterations from the stop criterion changes. To derive an acceptable reflective measurement model, 2 steps have to be taken into consideration namely; reliability (reliability of construct measures indicator and internal consistency reliability) and validity (convergent and discriminant). Out of 33 items, four factors loaded below 0.7 recommended thresholds for factor loading but due to the stage in the research this factors were still considered and compared to the composite reliability for any stringent effects. Thus, the measurement model achieved a considerable level of indicator reliability levels. The composite reliability values revealed that all construct measures achieved a healthy score of above 0.7 which reflects a satisfactory level of internal consistency. For the convergent validity the AVE table was assessed denoting all construct scaled the 0.5 threshold. Discriminant validity was analysed through matching the cross loading values in Smart PLS which 
showed no construct cross loaded more than 0.2 of the leading item. Furthermore, the [50] specifications for discriminant validity was utilised. It specifies that the construct AVE should be higher than the correlation of all opposing constructs. All construct measure according to this measurement model assessment showed reliability and validity.

The structural model focuses on the relationships between the hypothesized various in the construction industry namely; BIM Perception (people, process and technology), Strategic IT Implementation (business process re-engineering and computer integrated construction), collaborative construction and BIM penetration. Figure 2 shows the results from SmartPLS using the earlier stated parameters. Following [42] recommendations, the central criterion for the structural model assessment is given by the coefficient of determination $R 2$. The $R 2$ for BIM Penetration derived 0.25. $R 2$ for CC derived 0.47. $R 2$ for BPR derived 0.36. $R 2$ for CIC derived 0.48 . The average value of $R 2$ depicts the models predictive validity [42]. From the path weights, 0.56 of technology represents the highest variable affecting BPR in the industry. 0.47 of process has d highest impact in CIC. 0.44 of BPR represented the highest impact on BIM penetration in the industry. The bootstrapping technique was later carried out to derive the level of significance [41] [42]. Figure 3 shows that most hypothesized relationships are significant except for the following; process $\rightarrow$ CC $(1.33, \mathrm{p}<0.05)$, process $\rightarrow$ BPR $(0.86, \mathrm{p}<0.05)$, BPR -> BP (0.80, p < 0.05), People -> BP (1.48 p < 0.05), Technology -> BP $(1.50 \mathrm{p}<$ $0.05)$ and Technology $->$ CIC $(0.99 \mathrm{p}<0.05)$. The highest significance values occurred between technology and BPR (9.87, $\mathrm{p}<0.05)$.

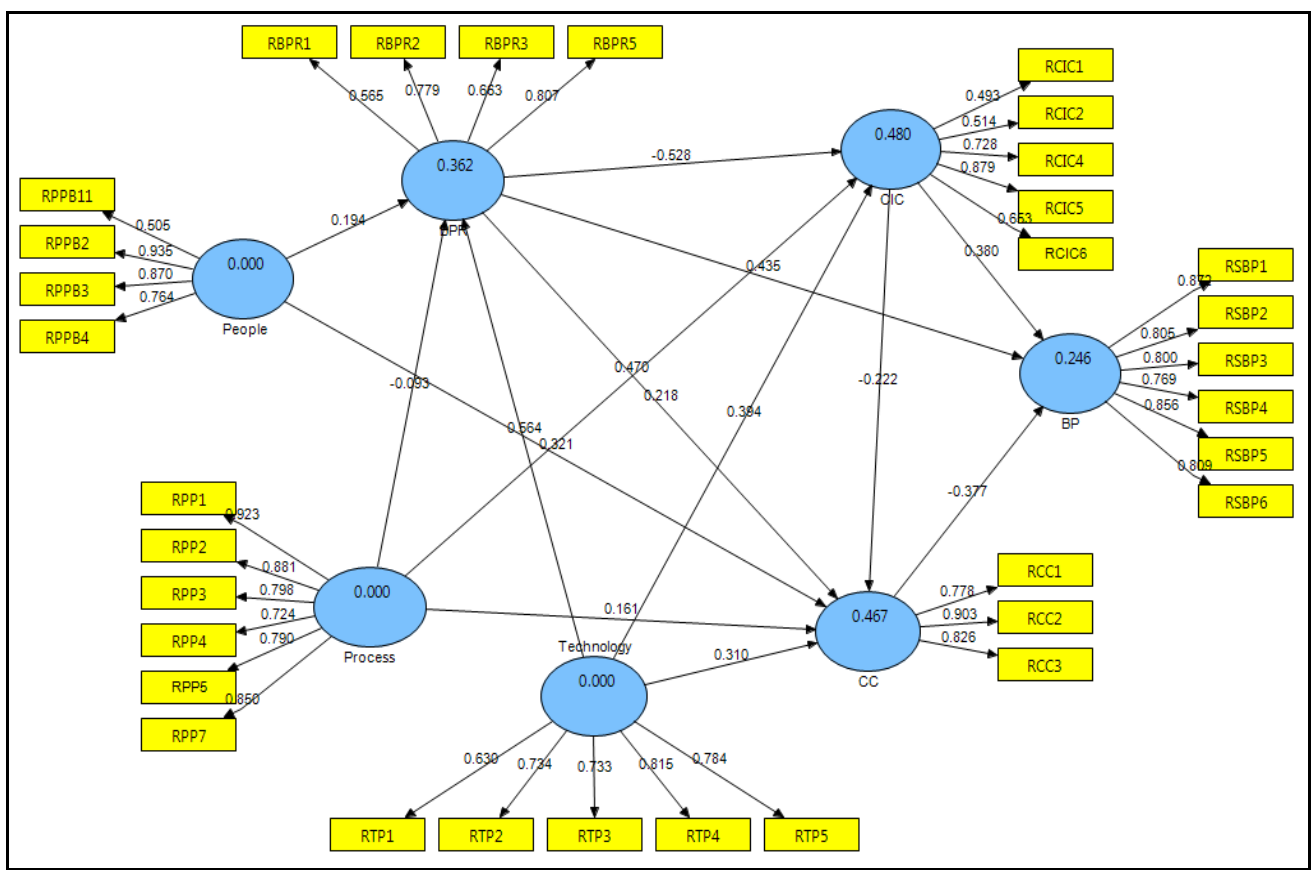

Fig 2. Measurement Model 


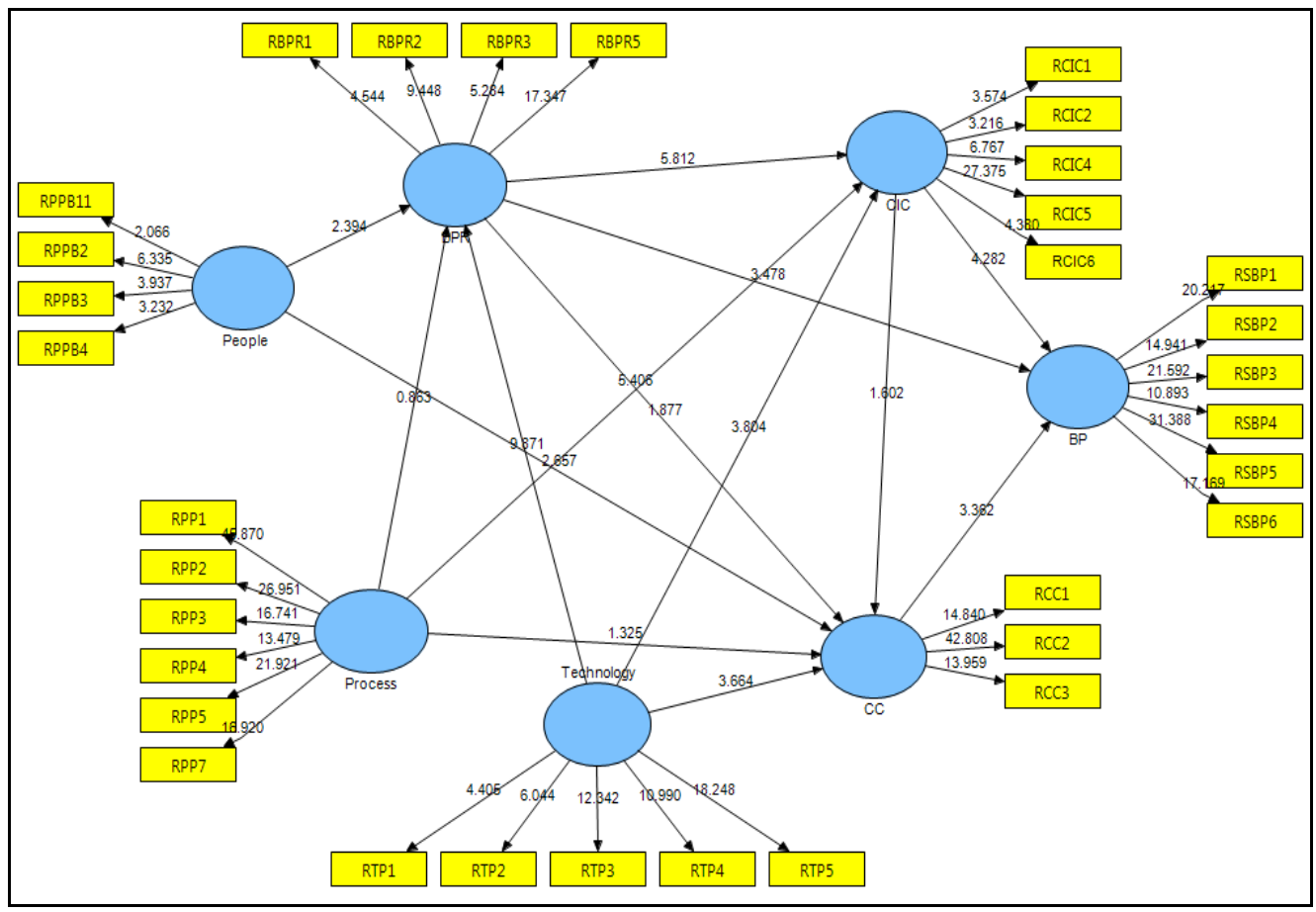

Fig 3. Bootstrapping (T statistics, >1.96 significant at 0.05 at $95 \%$ confidence level)

\section{Conclusion}

This paper set out to examine the varying factors affecting BIM penetration in the industry, accomplished through an extensive literature study to define the key variables. The hypothesized model and subsequent hypothesis was presented. The instrument for the main study showed a healthy Cronbach alpha including achieving discriminant validity amongst the model variables. A test of the hypothesized variables showed most importantly that $24.6 \%$ of BIM penetration can be explained by the model considering the sample size. Seemingly, the effects of technology had a highest influence on BPR, conforming with previous standpoint that technology enabler's drive towards strategic innovation and leads to changes to traditional business processes [30] [27] [31] [51] [32]. In the long run therefore BPR weighed heavily on BIM penetration in the industry. Efforts such as seminars and conference to promote BIM by organisations such as CIDB, BQSM, RISM and software vendors sponsored by individual firms shows there is indeed a drive towards change [13]. How Malaysian construction industry professional view process change weighed heavily on CIC, thus follows prior research linking CIC to improvement in communication, planning, collaboration, and databases [52] [20]. These findings contribute immensely to the body of knowledge in the field of global BIM study as it present a total outlook on several variables determining BIM penetration in the industry. Prior research studied presented a division in various aspect of BIM research pointing to key limiting factors as people, process and technology [22] [14] [54] [5], further studies define technology adoption [55], similar to such limiting factors while 
this research combined other factors. [19] recommended a follow up research on BIM readiness in Malaysia from a more quantitative approach. This research provides numerical figures though with limiting sample size still in a pilot phase. The findings points a path for major managerial decision making choices as to which areas in the construction industry to improve upon. These bodies are not limited to Construction Research Institute of Malaysia (CREAM) and Construction Industry Development Board of Malaysia (CIDB), Malaysian BIM committee, Malaysia Engineer Boards actively in the fore-front for BIM total implementation. The interrelationship found in the model denotes that prompt attention be given to areas such as BPR in the industry. The successes from JKRs BIM pilot project (National Cancer Institute) will push for future changes in BPR in Malaysia [56] [19]. The results of this research explicate the strategic role of BIM and the ability of construction professionals to deal with the dynamics of BIM adoption and use. This research contributes to both theory and practice on BIM and technology adoption by developing and validating the research instrument. Future research will not only look into extension of the model but also seek to test various mediating variables and varied sample population testing.

\section{References}

1. Enegbuma, W.I. and Ali, K.N. (2013). Hypothesis Analysis of Building Information Modelling Penetration in Malaysian Construction Industry. Proceedings of CIB World Building Congress 2013, 5th - 9th May, Brisbane, Australia.

2. Rosenberg, T.L. (2006). Building Information Modelling. Retrieved from http://www.ralaw.com/resources/documents/Building\%20Information\%20Modeling\%20\%20Rosenberg.pdf.

3. Hammond, D. M. (2008). The BIM Balancing Act. Journal of Building Information Modelling. Fall 2008 issue, pp. 12-14.

4. Rezgui, Y. and Zarli, A. (2006). Paving the Way to the Vision of Digital Construction: A Strategic Roadmap. Journal of Construction Engineering and Management, 132(7), 767-776.

5. East, E.W. (2009). Performance Specifications for Building Information Exchange. Journal of Building Information Modelling, Fall 2009 Issue, pp. 18-20.

6. Enegbuma, W.I. and Ali, K.N. (2012). A Theoretical Framework for Building Information Modelling Penetration in Malaysian Construction Industry. Proceedings of Management in Construction Research Association (MiCRA) Post Graduate Conference, Kuala Lumpur, Malaysia.

7. Hampson, K. and Kraatz, J. (2013). Modelling, Collaboration and Integration: A Case Study for the Delivery of Public Buildings. Proceedings of International Council for Research and Innovation in Building and Construction (CIB) World Building Congress 2013, 5th - 9th May, Brisbane, Australia.

8. Hjelseth, E. (2013). Integrated Approach for Development of Automatic Building Application Systems. Proceedings of International Council for Research and Innovation in Building and Construction (CIB) World Building Congress 2013, 5th - 9th May, Brisbane, Australia.

9. Succar, B. (2009). Building Information Modelling Framework: A Research and Delivery Foundation for Industry Stakeholders. Automation in Construction, Vol. 18: 357-375.

10. Allen Consulting Group (2010). Productivity in the Buildings Network, Built Environment Industry Innovation Council, Canberra, Australia.

11. Hartmann, T. and Fischer, M. (2008). Applications of BIM \& Hurdles for Widespread Adoption of BIM. CIFE Working Paper, CIFE, US.

12. DIISR (2010). Department of Innovation, Industry, Science and Research. Issues Paper: Digital Modelling \& the Built Environment, Commonwealth of Australia, Aust.

13. Ali, K.N., Al-Jamalullail, S.N.N.I. and Boon, T.C. (2013). Building Information Modeling Awareness and Readiness: Among Quantity Surveyors and Quantity Surveying Firms. Selangor: Royal Institution of Surveyors Malaysia (RISM).

14. Jordani, D. (2008). BIM: A Healthy Disruption to a Fragmented and Broken Process. Journal of Building Information Modelling, Spring 2008 issue, pp. 24-26. 
15. Salmon, J.L. (2009). The Legal Revolution in Construction: How collaborative Agreements, BIM and Lean Construction Methods Support Integrated Project Delivery. Journal of Building Information Modelling. Spring 2009 issue, pp. 18-19.

16. Lega, A. (2008). Synergy in the Sandbox. Journal of Building Information Modelling, Fall 2008 issue, pp. 44-46.

17. Edgar, A. (2008). Building Value through Building Information Innovation. Journal of Building Information Modelling, Spring 2008 issue, pp. 38.

18. Henderson, L. and Jordan, N.L. (2009). A Modest Proposal for a Transdisciplinary Curriculum: for the Design, Construction, Management and Maintenance of Architecture. Journal of Building Information Modelling. Fall 2009 issue, pp. 35-37.

19. Haron, A. T. (2013). Organisational Readiness to Implement Building Information Modelling: A Framework for Design Consultants in Malaysia. PhD Thesis School of the Built Environment Faculty of Business, Law and the Built Environment, University of Salford Manchester, Salford.

20. Aouad, G., Cooper, R., Kaglioglu, M. and Sexton, M. (1999). An IT-supported New Process, Strategic Management of IT in Construction, (Editor Martin Betts), Blackwell Science, pp 363-375.

21. Yan, H. and Damian, P. (2008). Benefit and Barriers of Building Information Modelling. $12^{\text {th }}$ International Conference on Computing in Civil and Building Engineering.

22. Liu, Z. (2010). Feasibility Analysis of BIM Based Information System for Facility Management at WPI. Worcester Polytechnic Institute, Worcester, Massachusetts, US.

23. Smith, D. (2007). An Introduction to Building Information Modeling (BIM). Journal of Building Information Modelling. Fall 2007 issue, pp. 12-14.

24. Ibrahim, A.R., Roy, M.H., Ahmed, Z. and Imtiaz, G. (2010). An Investigation of the Status of the Malaysian Construction Industry. Benchmarking: An International Journal, 17(2), 294-308.

25. Jones, S.A. and Lien, J.K. (2008). Towards Interoperable Building Product Content. Journal of Building Information Modelling, Fall 2008 issue, pp. 36-37.

26. Onuma, K. (2008). Integration Today Using Open Standards: BIMStorm ${ }^{\mathrm{TM}}$, Rotterdam to Los Angeles and Beyond. Journal of Building Information Modelling, Spring 2008 issue, pp. 14-18.

27. Betts, M. (1999). Strategic Management of IT in Construction. Blackwell Science Ltd, Oxford.

28. Alshawi, M. (2007). Rethinking IT in Construction and Engineering: Organisational Readiness. Taylor and Francis, London and New York.

29. Kuppusamy, M. and Shanmugam, B. (2007). Islamic Countries Economic Growth and ICT Development: The Malaysian Case. Journal of Economic Cooperation, 28(1): 99-114.

30. Davenport, T. (1993). Process Innovation: Re-engineering Work through Information Technology. Havard Business School Press. Boston, MA.

31. Liang, Y. and Cohen, E. (1994). Business Process Re-engineering: An Overview. South-Central Small College Computing Conference. Amarillo, April 15-16. pp 130-136.

32. Kohar, U.H.A., Senina, A.A., and Ismaila, K. (2012). The Cultivation of Organizational Innovation amongst Malaysian Bumiputera (Indigenous) ICT-Based Small Firms. Procedia - Social and Behavioural Sciences 40: 358 - 363.

33. Anumbe, C.J., Ugwu, O.O., Newnham, L. and Thorpe, A. (2001). A Multi-Agent System for Distributed Collaboration Design. Journal of Logistics Information Management, 14(5\&6): 355-66 (Special Issue on Softwares and Methods for Improving Decision-Making in Civil Engineering).

34. Sun, M. and Aouad, G. (2000), Integration Technologies to Support Organisational Changes in the Construction Industry. 7th ISPE International conference on Concurrent Engineering. Lyon, France, 596-604.

35. Anumbe, C.J., Ugwu, O.O., Newnham, L. and Thorpe, A. (2002). Collaborative Design of Portal Frame Structures using Intelligent Agents. Automation in Construction, 11(1): 89-103.

36. Lang, S.Y.T., Dickinson, J. and Bucha, R.O. (2002). Cognitive Factors in Design, Computers in Industry, 48: 89-98.

37. Panuwatwanich, K., Stewart, R.A. and Mohamed, S. (2009). Critical Pathways to Enhanced Innovation Diffusion and Business Performance in Australian Design Firms. Automation in Construction 18: 790797.

38. Mitropoulos, P. and Tatum, C.B. (2000). Forces Driving Adoption of New Information Technologies. Journal of Construction Engineering Management. 2000.126:340-348.

39. Rogers, E.M. (1983). Diffusion of innovations, Free Press, New York

40. Joreskog, K.G. (1982). The LISREL Approach to Causal Model-Building in the Social Sciences. In: Wold, H., Joreskog, K.G. (Eds.), Systems under Indirect Observation, Part I. North-Holland, Amsterdam, pp. 81-100. 
41. Hair, J.F., Hult, G.T.M., Ringle, C.M. and Sarstedt, M. (2013). A Primer on Partial Least Squares Structural Equation Modeling (PLS-SEM). Sage, Thousand Oaks.

42. Henseler, J., Ringle, C.M. and Sarstedt, M. (2012). Using Partial Least Squares Path Modeling in International Advertising Research: Basic Concepts and Recent Issues. In: Okazaki, S. (Ed.), Handbook of Research in International Advertising. Edward Elgar Publishing, Cheltenham, pp. 252276.

43. Henseler, J., Ringle, C.M. and Sinkovics, R.R. (2009). The Use of Partial Least Squares Path Modeling in International Marketing. Advances in International Marketing 20, 277-320.

44. Lu, I. R. R., Kwan, E., Thomas, D. R. and Cedzynski, M. (2011). Two New Methods for Estimating Structural Equation Models: An Illustration and a Comparison with two Established Methods. International Journal of Research in Marketing 28 (3): 258-268.

45. Pinto, J. R., Rodriguez-Escudero, A. I. and Gutierrez-Cillan, J. (2008). Order, Positioning, Scope and Outcomes of Market Entry. Industrial Marketing Management, 37(2), 154-166.

46. Ringle, C.M., Wende, S. and Will, A. (2005). SmartPLS 2.0 M3. Available at http://www.smartpls.de.

47. Chin, W.W. (2010). How to Write Up and Report PLS Analyses. In: Vinzi, V.E., Chin, W.W., Henseler, J. and Wang, H. (Eds.), Handbook of Partial Least Squares: Concepts, Methods and Applications (Springer Handbooks of Computational Statistics Series, Vol. II). Springer, Heidelberg, Dordrecht, London, New York, pp. 655-690.

48. Diamantopoulos, A., Sarstedt, M., Fuchs, C., Sebastian, S. and Wilczynski, P. (2012). Guidelines for Choosing between Multi-Item and Single-Item Scales for Construct Measurement: A Predictive Validity Perspective. Journal of the Academy of Marketing Science 40 (3): 434-449.

49. Cronbach, L.J. (1951). Coefficient Alpha and the Internal Structure of Tests. Psychometrika, 15: 297334.

50. Fornell, C.G. and Larcker, D.F. (1981). Evaluating Structural Equation Models with Unobservable Variables and Measurement Error. Journal of Marketing Research 18 (1), 39-50.

51. Too, E. and Tay, L. (2003). Implementing Construction and Real Estate IT Education: Needs and Strategy. In Proceedings the 10th European Real Estate Society Conference, Helsinki, Finland

52. Arayici, Y., Ahmed, V. and Aouad, G. (2005). A Requirements Engineering Framework for Integrated Systems Development for the Construction Industry. ITcon. Vol. 11: 35.

53. Arayici, Y. and Aouad, G. (2004), DIVERCITY: Distributed Virtual Workspace for Enhancing Communication and Collaboration Within the Construction Industry. European Conference on Product and Process Modelling in the Building and Construction Industry (ECPPM), Istanbul, Turkey: 415422.

54. Wong, K.A., Wong, K.F. and Nadeem, A. (2011). Government Roles in Implementing Building Information Modelling Systems: Comparison between Hong Kong and the United States. Construction Innovation, 11(1): 61-76.

55. Taylor, S. and Todd, P.A. (1995). Understanding Information Technology Usage: A Test of Competing Models. Information Systems Research 5(2): 144-176.

56. Sani, R. (2010). Modelling for Better Buildings. New Straits Times, 16 August, p. 21. 